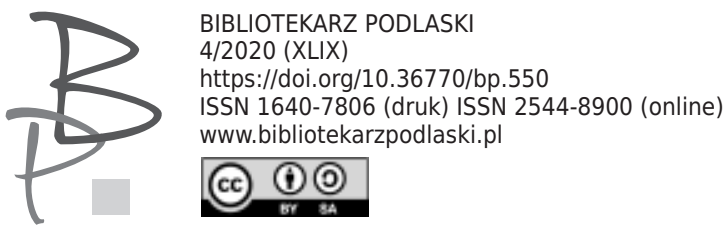

\author{
Jarosław Poliszczuk* \\ Uniwersytet im. Adama Mickiewicza w Poznaniu \\ https://orcid.org/0000-0001-9081-7900
}

\title{
Ukraińska wizja Słowiańszczyzny
}

Ukrainian vision of the Slavic Land

Abstract: The research is dedicated to the development of Slavic ideas during the Ukrainian romantic circles of adherents, namely in the secret circle, called Brotherhood of Saints Cyril and Methodius, which worked in Kyiv during the years 1846-1847. That comradeship represented its own original understanding of Slavic uncertainty. After it was eliminated by the regime of Russian Imperia all Slavophil movements were stopped and theirs participants were persecuted and arrested. That's why the author of this article treats the year 1847 as a year of Kyiv arresting conspirators and a time of change in the development of Slavic ideology.

Keywords: slavophilism, Brotherhood of Saints Cyril and Methodius, society, Slavic idea, Russian imperia.

* Jarosław Poliszczuk - prof. dr hab., pracownik Zakładu Ukrainistyki Uniwersytetu imienia Adama Mickiewicza w Poznaniu; ostatnio opublikował książki Reaktywność literatury (Реактивність літератури, Київ 2016) oraz Topografia hybrydowa. Miejsca i nie-miejsca we współczesnej literaturze ukraińskiej (Гібридна топографія. Місия і не-місия в сучасній українській літературі, 2018). 


\section{Romantyczna idea wspólnoty}

$\mathrm{Na}$ debiuty romantyków składają się nie tylko ogłoszenia drukiem dzieł poszczególnych twórców. W szerszym ujęciu podobne debiuty należy przecież traktować jako prezentacje wspólnego stanowiska intelektualistów, jako świadectwa powstania formacji romantycznej z postępowym wyprecyzowaniem wspólnego światopoglądu i programu działań. Adaptacja idei europejskiego oświecenia oraz romantyzmu na gruncie kultur słowiańskich miała swoje osobliwości, spowodowane między innymi stanem zniewolenia narodów słowianskich w owym okresie. Niemniej jednak to właśnie romantyzm przyczynił się do nobilitacji ludu, jego historii oraz kultury, co posłużyło odrodzeniu ambicji narodowo-wyzwoleńczych w wielu środowiskach.

Idąc w ślad niemieckiego myśliciela Johanna Gottfrieda Herdera, twórcy słowiańscy przyznają swoim rodakom szczególną rolę w przyszłym rozwoju cywilizacji europejskiej. Procesy kształtowania świadomości narodowej wśród ludów słowiańskich w okresie romantyzmu nasilają się z niezwykłą prędkością, a ich siłą napędową są odwołania do poczucia wspólnego pochodzenia, spokrewnionych języków bądź wspólnego dziedzictwa kulturowego. Aspiracje twórcze Słowian skupiają się głównie wokół kultury ludowej - języka, folkloru, pojmowania dziejów, co wynika z potrzeby poznania prawdziwego ducha naro$d u$ (Herder używał tego pojęcia - Volkgeist ${ }^{1}$ ), ponieważ to właśnie on jest czynnikiem historiotwórczym. Prowadzono zatem rzetelne badania nad przeszłością ludów słowiańskich, a język i folklor zostały głównymi filarami wyeksponowania i prezentowania oryginalności kultury słowiańskiej na szerszą skalę. Tego typu działania tworzyły fundament dla doktryny słowiańskiej i - co najważniejsze - budziły nadzieję przywrócenia utraconej niegdyś niepodległości, uzyskania praw autonomicznych w przyszłej federacji spokrewnionych narodów bądź nobilitacji poszczególnych ludów w zakresie procesu historycznego.

Analiza debiutu romantyków w szerokim kontekście kulturowym przyczyni się do uwzględnienia nie tylko debiutanckich utworów poszczególnych

1 R. Wisbert, Historia i edukacja w koncepcjach Johanna Gottfrieda Herdera, [w:] Rozum i świat. Herder i filozofia XVIII, XIX i XX wieku, red. M. Heinz, M. Potępa i Z. Zwoliński, Warszawa 2004, s. 162. 
twórców, lecz także do zaobserwowania ewolucji całej formacji romantycznej, losy której w XIX-wiecznej Europie Środkowo-Wschodniej potoczyły się przecież dość dramatycznie.

Słowianofilstwo w tej historycznej scenerii jawi się jako ideologia istnie romantyczna, która przyczyniła się do wzajemnego poznawania się i, co najbardziej istotne, do zbliżenia słowiańskich narodów poprzez wzmocnienie ich kontaktów kulturowych. Epoka romantyków była z tego punktu widzenia bardzo dynamiczna i owocna, towarzyszyło jej wiele inicjatyw w tym zakresie, a postrzeganie kwestii słowiańskiej uległo znacznej ewolucji - od naiwnych marzeń intelektualistów do rozmaitych prób podporządkowania wątków przyjaźni słowiańskiej ideologii imperialnej - bądź to w carskiej Rosji, bądź w Imperium Austro-Węgierskim. Ogólnie rzecz biorąc, należy przyznać, iż tendencja upolitycznienia ruchu słowiańskiego wreszcie zdominowała wiek XIX, mimo że w swojej ewolucji doświadczyła wiele interesujących zjawisk. O ile w pierwszej połowie stulecia słowianofilstwo okazało się ideologią budującą, o tyle w późniejszym okresie straciło na aktualności, ustępując miejsca koncepcji narodowej, ucieleśniając się w projekty poszczególnych narodów słowiańskich.

Właśnie okres lat 30-40. XIX wieku okazał się najbardziej sprzyjającym dla idei słowiańskiego odrodzenia. W historii politycznej ów etap został napiętnowany dwiema datami - 1830 oraz 1848. Pierwsza upamiętnia polskie powstanie narodowe, które wybuchło w listopadzie i trwało prawie przez rok (właściwie 1830-1831). Powstanie listopadowe przyspieszyło przebudzenie narodowe całego regionu, przede wszystkim w granicach Imperium Rosyjskiego. Z kolei rok 1848 odznaczył się rewolucją w Imperium Habsburgów, która spowodowała aktywizację narodowo-wyzwoleńczych ruchów w tej części kontynentu i w pewnym stopniu w całej Europie Środkowo-Wschodniej. Bez wątpienia w procesach dążeń oraz przemian rewolucyjnych odegrali bardzo ważną rolę genialni poeci i publicyści, reprezentując wolę zbiorową swoich narodów oraz właściwy duch Wiosny Ludów w całości, tej miary, co Ján Kollár, Adam Mickiewicz, Vuk Karadžić, L'udovít Štúr, France Prešeren etc. Publiczne apele wybitnych poetów Słowiańszczyzny przybliżały uzyskanie przez ich narody podmiotowości kulturowej i politycznej w ówczesnej Europie. Z innej strony apele te świadczyły o postępowej ewolucji idei słowiańskiej - od nostalgicznych odwołań do prehistorycznej jedności oraz marzeń 
o wspólnej przyszłości do promowania idei narodowej, która została wyraźnie zarysowana w dziełach twórców romantycznych.

W tym artykule rozważamy los ukraińskiej wizji Słowiańszczyzny, skupiając uwagę na okresie 1846-1847, to jest na przededniu Wiosny Ludów. Czas ten wypada postrzegać jako przełomowy nie w zakresie historii politycznej, lecz w zakresie historii kultury Słowian Wschodnich. Właśnie wtedy, jak się wydaje, doznał przełomu ruch „słowiańskiej wzajemności” (Ján Kollár), a także dokonał się jego właściwy rozłam na dwie gałęzie o odpowiedniej orientacji politycznej. Myślicieli słowiańscy, świadomi słabości dążeń narodowowyzwoleńczych w okresie wielkich mocarstw oraz ich potęgi militarnej, przymierzali się do układu ówczesnej Europy, pragnąc wzmocnić w niej pozycje narodów słowiańskich. W ten sposób kształtowała się doktryna austroslawizmu z jednej strony, ale $\mathrm{z}$ drugiej też - koncepcja słowianofilstwa rosyjskiego, zahamowana w swoim rozwoju po roku 1847, jak będzie pokazane w ciągu dalszym rozważań. Tak czy owak, obydwie historyczne odmiany idei słowiańskiej doświadczyły mocnej presji politycznej, chociaż ich rozwój w XIX wieku pokazuje także płynność i zawirowania polityki imperialnej zarówno Austro-Węgier, jak i Rosji. Ówczesne słowianofilstwo trudno przecież wyobrazić sobie w „czystym” kształcie - jako autonomiczny ruch literatów i uczonych, mimo że jego uczestnicy właśnie w ten sposób postrzegali swoją pracę na rzecz kultury rodzimej. Ideologia słowiańska jednakże była skazana na zaangażowanie w rozmaite manipulacje o kształcie politycznym² ${ }^{2}$. Współczesny rosyjski badacz Aleksiej Miller pisze o tym:

Panslawizm rosyjski był skierowany do Słowian habsburskich w nie mniejszym stopniu, niż do Słowian osmańskich. Czesi i Słowacy, nie mówiąc już o galicyjskich Rusinach, byli wcale wrażliwi wobec tej propagandy. Ale nierzadko w środowisku austriackich Słowian panslawizm ulegał bardzo istotnym zmianom, w tym przekształcając się w austroslawizm, co przewidywał lojalność wobec Habsburgów³.

2 Т. Георгиева, Славянската идея в Русия. 30-те-50-те години на ХІХ век, София 2009; А. Зорин, Кормя двуглавого орла... Литература и государственная идеология в России в последней трети XVIII - первой трети XIX века, Москва 2004.

3 Tutaj i w ciągu dalszym (o ile nie zaznaczono inaczej) thumaczenie własne. W wersji oryginalnej: «Российский панславизм был адресован габсбургским славянам не менее, чем османским. Чехи и словаки, не говоря уже о галицийских русинах, были весьма $\rightarrow$ 
Wypadałoby dodać, że do podobnej lojalności, tym razem w jeszcze bardziej otwartej i kategorycznej formie, skłaniały intelektualistów słowiańskich władze mocarstwa Rosyjskiego, o czym świadczy przytoczony poniżej przykład zaangażowania w ideę słowiańską kijowskich intelektualistów.

U progu rewolucji 1848 roku ideologia słowiańska miała nie tylko gorących zwolenników w środowisku romantyków, ale także rozsądnych krytyków. Koncepcja Jána Kollára ogłoszona w znanym artykule programowym O literackiej wzajemności między różnymi szczepami i narzeczami narodu stowiańskiego (O literárnej wzájemnosti mezi kmeny a nářečími slavskými, 1836) została zweryfikowana przez samo życie, gdyż marzenie o wspólnym języku literackim okazało się utopią i nie powstrzymało rozwoju żywych języków poszczególnych plemion słowiańskich. Podczas Pierwszego Zjazdu Słowiańskiego, który został zwołany w Pradze w roku 1848, František Palacký zaprezentował koncepcję austroslawizmu uwzgledniającą obecne status quo narodów słowiańskich, zamieszkujących (oprócz większości Polaków oraz Słowian Wschodnich) tereny Imperium Habsburgów. Austroslawizm promował federalny ustrój państwa po rewolucji, bo właśnie taki ustrój był w stanie zaspokoić potrzeby oświatowo-kulturalne (częściowo także polityczne) Słowian przy zachowaniu uformowanego systemu całego państwa.

Inna, prorosyjska wizja Słowiańszczyzny została zaprezentowana na II Zjeździe Słowiańskim, który był zorganizowany w Moskwie w 1867 roku, po upływie prawie dwudziestu lat i po dokonaniu odpowiednich przemian politycznych w Europie Środkowo-Wschodniej. Na marginesie warto przypomnieć, że ideologia słowiańska, choć z mniejszym efektem, była wykorzystywana na różne sposoby także w wieku XX: ona przyświecała Józefowi Stalinowi w utworzeniu Komitetu Wszechsłowiańskiego, działającego w okresie drugiej wojny światowej i powojennego podporządkowania narodów środkowoeuropejskich (1941-1948), tak samo inspiruje imperialistów rosyjskich nawołujących do jedności Słowian obecnie, w prowadzonych przez Rosję akcjach militarnych na Ukrainie, w Mołdawii bądź w innych państwach.

$\rightarrow$ восприимчивы к этой пропаганде. Но нередко в среде австрийских славян панславизм претерпевал весьма существенные изменения, в том числе превращаясь в австрославизм, который предполагал лояльность Габсбургам». А. Миллер, Империя Романовых и наиионализм. Эссе по методологии исторического исследования, Moskwa 2008, s. 34-35. 
W pierwszej połowie XIX stulecia ujawniają się pewne różnice pomiędzy poszczególnymi wizjami w zakresie poglądów słowianofilskich. Jest to całkiem zrozumiałe, gdyż odzwierciedla różne podejście twórców słowiańskich wobec kwestii politycznych, społecznych, kulturalnych, wyznaniowych. Nie da się zlekceważyć w tym względzie oddziaływania elit obu mocarstw - Romanowów oraz Habsburgów, czyli Rosji oraz Austrii. W swoim czasie tego typu różnice zaobserwował wybitny slawista Dymitr Czyżewski, który pisał:

Pierwsi słowianofile (przeważnie ze środowiska Słowian Zachodnich i Południowych) w formie dość umiarkowanej nawoływali do jedności kulturowej Słowian, w której upatrywali wzajemną akceptację w życiu kulturalnym i - dopiero częściowo - politycznym. Właśnie takimi byli wybitni działacze odrodzenia czeskiego i słowackiego (Ján Kollár i Pavol Šafárik), którzy między innymi idealizowali „słowiańską duszę". Ruscy słowianofile składają druga grupę w tym nurcie ideologicznym, poza nielicznymi wyjątkami słabo wyobrażali sobie inne słowiańskie narodowości: duchowo utożsamiali się oni z bizantyjskim prawosławiem, wszelako udowodnili obecność istotnych różnic pomiędzy słowiańskim i zachodnioeuropejskim światem ${ }^{4}$.

\section{Z perspektywy kijowskiej}

W myśli intelektualistów ukraińskich zrzeszonych w Bractwie Słowiańskim św. Cyryla i Metodego (1846-1847) obydwie wspomniane wyżej postawy próbowano pogodzić ze sobą, a nade wszystko stwierdzić ideę bytu i przeznaczenia młodego narodu ukraińskiego, który, podobnie do innych narodów słowiańskich, wyartykułował w ten sposób ambicje do emancypacji kulturowej i częściowo politycznej. Hasła przebudowy społeczeństwa głoszone przez cyrylometodyjczyków kijowskich wydawały się całkiem aktualne w obliczu despotycznych rządów mocarstwa rosyjskiego. Tym bardziej, że Bractwo deklarowało przemiany społeczne, oparte wyjątkowo na zasadach nauki chrześcijańskiej, oraz reformy demokratyczne, prowadzone $w$ interesie każdego obywatela, bez podziału na warstwy, odrzucając hierarchię społeczną. Mimo że poglądy cyrylometodyjczyków - marzenie o zjednoczeniu wszysts. $175-176$.

4 Д. Чижевський, Порівняльна історія слов'янських літератур, пер. 3 нім., Kijów 2005, 
kich Słowian w przyszłym demokratycznym państwie w kształcie federacji - były w dużym stopniu idealistyczne i niekoniecznie liczyły się z realiami politycznymi, ich wizja Ukrainy i Słowiańszczyzny jest bardzo reprezentacyjna jak na owe czasy5. Poza tym jawi się jako swoisty punkt dojścia w rozwoju romantycznej, wyimaginowanej i wyidealizowanej koncepcji Słowiańszczyzny. $\mathrm{Z}$ upływem czasu traciła na takim znaczeniu, ulegając trendom myślenia pozytywnego w II połowie XIX wieku.

Tajne Bractwo św. Cyryla i Metodego zostało założone w Kijowie na przełomie lat 1845-1846, zrzeszało członków wokół idei słowiańskiej solidarności i wzajemności, a także wzmacniało ich marzenia o przyszłej federacji narodów słowiańskich na zasadach wolności, równości i autonomii. Poglądy i losy członków tej organizacji były w swoim czasie badane przez uczonych ukraińskich ${ }^{6}$, a wyniki prac opublikowano w językach ukraińskim i rosyjskim ${ }^{7}$ Kwestii Bractwa i jego oddziaływania na kulturę ukraińską zostały poświęcone także prace polskich badaczy: Stefana Kozaka ${ }^{8}$, Włodzimierza Mokrego ${ }^{9}$ i innych. Słusznym uzupełnieniem tych badań jest publikacja rozmaitych dokumentów dotyczących śledztwa i procesu ${ }^{10}$, wytyczonego cyrylometodyjczykom w Petersburgu w roku 1847.

Nieprzypadkowo ideę Bractwa św. Cyryla i Metodego realizowano właśnie w Kijowie, gdzie od czasów Średniowiecza nurty prosłowiańskie miały bardzo mocne uzasadnienie kulturowe - w postaci państwa Rusi Kijow-

5 Historia Bractwa może być również pomyślnie interpretowana w kontekście współczesnych badań nad kulturą, jak świadczy Mariya Bracka w niedawno opublikowanym artykule, w którym podejmuje się oceny tego zjawiska z punktu widzenia teorii postkolonialnej: M. Bracka, Idee kijowskiego Bractwa Cyryla i Metodego (1846-1847) w świetle krytyki postkolonialnej, „Bibliotekarz Podlaski” 2015, nr 30, s. 43-55.

6 М. Возняк, Кирило-Мефодї̈вське Братство, Львів 1921; Д. Чижевський, Нарис з історії філософії на Украӥні, New York 1991; М. Бойко, Кирило-Мефодіївське товариство: філософські та культурологічні ідеї національної самосвідомості та державотворення, Дніпродзержинськ 2006; Я. Козачок, О. Горленко, Забуттю не підлягає. Микола Костомаров і Кирило-Мефодіївське товариство, Київ 2007.

7 П. Зайончковский, Кирилло-Мефодиевское общество 1845-1847, Москва 1959.

8 S. Kozak, Ukraińscy spiskowcy i mesjaniści. Bractwo Cyryla i Metodego, Warszawa 1990; tenże, Polacy i Ukraińcy. W kręgu myśli i kultury pogranicza. Epoka romantyzmu, Warszawa 2005.

9 W. Mokry, Literatura i myśl filozoficzno-religijna ukraińskiego romantyzmu, Kraków 1990, s. $149-167$.

10 Кирило-Мефодївське товариство, упор. І. Глизь та ін. у 3 т., Kijów 1990. 
skiej jako wybitnego reprezentanta cywilizacji Słowian w przeszłości, czy w postaci bogatej kultury przesiąkniętej tradycją bizantyńską i cyrylometodiańską. Na Uniwersytecie św. Włodzimierza, który został powołany przez władze rosyjskie w roku 1834, to znaczy po stłumieniu powstania listopadowego jako przeciwwaga wpływom polskim na Ukrainie (wtedy - w Rosji Południowej), szybko doszło do zorganizowania inteligencji o poglądach postępowych. Tym razem w formie bractwa, co nawiązywało do znanych z okresu Renesansu i Baroku bractw cerkiewnych na Ukrainie, zrzeszających świadomych obywateli oraz promujących kulturę rodzimą (prawosławną) w Rzeczypospolitej ${ }^{11}$.

W okresie romantyzmu ideologia słowiańska zyskała sporo zwolenników nie tylko dlatego, że wyrażała poglądy postępowych intelektualistów, wzorowane na ideach zachodnioeuropejskich. Siłą rzeczy zawierała ona bardzo ważny pierwiastek wolnościowy, łączyła się z wizją odzyskania swobody dla zniewolonych narodów, których istnienie w obrębie ówczesnych mocarstw było przecież zagrożone. Hasła zjednoczenia Słowian były na czasie przez to, że wyrażały stanowisko przeciwstawienia się niezbędnemu w warunkach wynarodowienia małych ludów i plemion w wielkich mocarstwach, których polityka była skierowana na ich kompletną asymilację.

$\mathrm{Z}$ innej strony patrząc, granice kompromisu pomiędzy świadomością imperialną a zapotrzebowaniem kulturowym małych narodów były dość płytkie. Doktryny imperialne w zakresie narodowym nie zostały jeszcze w pełni wypracowane. To z kolei pozwoliło na rozpowszechnienie ideologii słowiańskiej, zwłaszcza w Imperium Rosyjskim, gdzie przecież kartę słowiańskości rozgrywano $\mathrm{w}$ interesie państwa. Władze rosyjskie nie były w stanie kompletnie zakazać słowianofilstwa, lecz próbowały go wykorzystać w swoim interesie. Poglądy członków Bractwa dotyczyły zresztą ważnych treści doktryny politycznej mocarstwa rosyjskiego, nie patrząc na to, że owe treści były interpretowane w sposób oryginalny i dosyć śmiały. Przecież według myśli hr. Uwarowa, zawartej w jego słynnej formule „prawosławie - samowładza - ludowość" (православие - самодержавие - народность), Rosja miała

11 Szerzej o zjawisku bractw cerkiewno-oświatowych i ich roli w życiu kulturalnym Ukraińców i Białorusinów w XVII wieku patrz: В.Соболь, Украӥнське бароко. Тексти і контексти, Warszawa 2015, s. 86-90. 
być państwem otwartym na świat i aspiracje innych narodów. Koncepcja ta, jak twierdzi rosyjski badacz Andriej Zorin, „była stworzona po zakończeniu okresu wojen oraz powstań i mierzyła w trwały okres pokojowy w rozwoju imperium, ale jej głównym zadaniem jest deklaracja stanowiska Rosji wobec cywilizacji europejskiej"12. Spiskowcy kijowscy wyraźnie akcentowali ów europejski kierunek rozwoju, ale metonimią ich dążeń europejskich zostaje pomysł związku narodów słowiańskich jako modelu demokratycznego rozwiązania kwestii narodowo-kulturalnych, w przeciwieństwie do despotycznego układu ówczesnej Rosji.

Wątki słowianofilskie, obecne w Kijowie także wcześniej (w postaci loży masońskiej itp.), nasilają się w miarę powstania uniwersytetu i wzmocnienia środowiska akademickiego, w którym idea Słowiańszczyzny wywoływała coraz większe zainteresowanie oraz wydawała się atrakcyjną. W sprawozdaniu carskiej służby bezpieczeństwa zachowały się opinie o popularności słowianofilstwa w kręgach ówczesnej warstwy wykształconej. Tak więc doktryna promowana w małym kółku młodzieży akademickiej przy Uniwersytecie Kijowskim znalazła odzew w szerszym kręgu odbiorców i zyskiwała sympatyków poza uczelnią - w mieście i w południowych guberniach ówczesnego państwa, na terenie całej Ukrainy. Notatka sporządzona dla cara Mikołaja I przez hrabiego Orłowa oddaje niejednoznaczność stanowiska władz wobec doktryny słowiańskiej:

Postępowanie w sprawie o Słowiańskim stowarzyszeniu św. Cyryla i Metodego pokazało, że idei odrodzenia w każdej ziemi narodu, języka, własnej literatury, ulepszenia bytu ludzi i zrzeszenia wszystkich plemion słowiańskich w jedną całość, nie należą jedynie do osób uczestniczących w Słowiańskim stowarzyszeniu. Zaangażowanie uczonych w podobne idee w naszych czasach stało się jak gdyby potrzebą niezbędną. [...] Idee słowiańskie nie mogły przecież nie zaistnieć także w Kijowie jako mieście, w którym znajduje się uniwersytet i które jest bliskie Słowianom Zachodnim ${ }^{13}$.

12 А. Зорин, Кормя двуглавого орла..., s. 30.

13 Zob. Кирило-Мефодївське товариство, упор. І. Глизь та ін. у 3 т., Kijów 1990, t. 3, s. 306 . 
Badacze nie mają jednego zdania wobec programu Bractwa. Tym bardziej trudno oceniać konsekwencje jego działalności, gdyż istniało krótko i zostawiło mało śladów na kartach dziejowych. Co prawda, w losach poszczególnych osób udałoby się prześledzić wpływy ich zaangażowania młodzieńczego, gdyż cyrylometodyjczycy w zasadzie nie wyrzekli się swoich przekonań do idei solidarności słowiańskiej i na różne sposoby to udowodnili w swoich późniejszych czynach bądź dziełach. Jak stwierdza Włodzimierz Mokry, „mimo wykrycia podziemnego Bractwa cyrylometodyjskiego, zasądzenia i ukarania jego głównych członków, wiele z przyjętych wówczas zamierzeń, celów oraz idei było przez poszczególnych pisarzy realizowanych w działalności literackiej, naukowej, religijnej i społecznej”'14.

Z kolei zachowane dokumenty tak samo nie mogą być postrzegane z pełnym zaufaniem przez ich subiektywny charakter bądź względy cenzuralne. Osoby najbardziej aktywne i opiniotwórcze w stowarzyszeniu - a byli to wybitni intelektualiści ukraińscy: Mykoła Kostomarow, Wasyl Biłozerski, Mykoła Hułak, Pantelejmon Kulisz i wreszcie Taras Szewczenko - wciąż toczyły ze sobą debaty i chyba nie zdążyły dojść do wspólnego, zharmonizowanego w pełni stanowiska wobec spraw nadrzędnych. Zauważyć wolno, że w okresie radzieckim fenomen Bractwa był zwykle interpretowany przez pryzmat jego czynu rewolucyjnego, co z całą oczywistością jest mocną przesadą. Na tym opiera się twierdzenie o podziałach wewnętrznych, nawet o rozłamie wewnątrz Bractwa, gdzie miało wykreować się skrzydło rewolucyjno-demokratyczne z Szewczenką na czele i drugie, „burżuazyjno-nacjonalistyczne” z Kostomarowem i Kuliszem. Podobne stereotypy są nie do przyjęcia w naszych czasach, mimo że w wielu opracowaniach naukowych przestarzałe oceny dają się we znaki, prezentując się nawet w lekkiej bądź zakamuflowanej formie. Nadeszła pora, by zweryfikować dotychczasowe opinie na temat Bractwa. Wytyczmy najważniejsze aspekty, aby w dalszym ciągu artykułu skupić uwagę na jednym z nich:

\section{Kwestia „rewolucyjności” Bractwa Słowiańskiego w Kijowie.}

W zakresie propagandy radzieckiej Bractwo było warte usprawiedliwienia jedynie z tego względu, że niby promowało idee rewolucyjne. Jednakże dokumenty i wspo-

14 W. Mokry, Literatura i myśl filozoficzno-religijna ukraińskiego romantyzmu, s. 150. 
mnienia świadczą, że jego członkowie nie zgłaszali pomysłów otwartego zwalczania władzy, lecz odwrotnie, opowiadali się za przemianami w sferze duchowej. Było to ich przemyślane stanowisko, przynajmniej jako liderów organizacji, których w żadnym sensie nie wypada uznać za rewolucjonistów. Cyrylometodyjczycy nie nawoływali bezpośrednio do walki z despotyzmem rosyjskim (mimo że ostro oceniali oni stan zniewolenia narodowego i poszukiwali dróg do wolności i równości narodów słowiańskich, w tym przede wszystkim rodaków Ukraińców). Preferowali jednakże drogę oporu duchowego wobec Imperium Rosyjskiego, dążąc do wypracowania takiego modelu społeczeństwa, które umożliwi ustrój federacji słowiańskiej na zasadach wolności, równości oraz sprawiedliwości, a także w zgodzie z chrześcijańskimi zapowiedziami prawdziwej wiary i miłości do bliźniego. Postawa gorliwego chrześcijaństwa najmocniej cechowała intelektualistów kijowskich, a ich wizja relacji człowieka ze społeczeństwem opierała się na zasadzie miłości chrześcijańskiej jako wartości nadrzędnej ${ }^{15}$.

Najwięcej spekulacji w tym zakresie skupiało się wokół postaci Tarasa Szewczenki (ze względu na radykalizm jego poglądów politycznych, za który zresztą został ciężko ukarany przez władze) i jego domniemanego wpływu na innych członków Bractwa. Wiadomo, że Szewczenko nie uczestniczył w zebraniach Bractwa, odbywając służbowe podróże po Ukrainie jako artysta malarz, a jego wpływ nie sprowadzał się przecież do pomysłów radykalnej zmiany ładu społecznego.

\section{Kwestia masowości}

Szacuje się, że członków Bractwa było ponad sto osób. Dane te jednak wypada podać w wątpliwość, gdyż pochodzą z doniesień tajnych informatorów carskiej służby bezpieczeństwa ${ }^{16}$. W rzeczywistości trudno oszacować liczbę członków Bractwa. Inna sprawa, że idee przez nich głoszone miały szeroki odzew w środowisku ówczesnej inteligencji, przy tym nie tylko ukraińskiej, lecz także wśród Rosjan i Polaków o postępowych poglądach. Specjalne apele

15 Tamże, s. 165.

16 Zob. Кирило-Мефодївське товариство, упор. І. Глизь та ін. у 3 т., Kijów 1990, t. 3 , s. 304-306; S. Kozak, Ukrainscy spiskowcy i mesjaniści. Bractwo Cyryla i Metodego, Warszawa 1990, s. 91. 
Bractwa, skierowane do przedstawicieli tych narodowości, świadczą o tym, jak ważne były w opinii członków podziemnej organizacji idee solidarności społecznej ${ }^{17}$.

\section{Kwestia rozlamu wewnętrznego}

Wydaje się, że teza o rozłamie w Bractwie jest tak samo bezkrytycznie odziedziczona po nauce radzieckiej, która podkreślała domniemany rewolucjonizm radykalnej części organizacji i, przeciwnie, wskazywała na konserwatywność poglądów Kostomarowa, Kulisza i innych. Badacze historii kijowskich spiskowców utrzymują, że kształtowanie nowego światopoglądu młodzieży ukraińskiej odbywało się wskutek dyskusji najbardziej aktywnych członków, to jest Mykoły Kostomarowa, Pantelejmona Kulisza, Tarasa Szewczenki, Mykoły Hułaka, Wasyla Biłozerskiego. Do rozłamu raczej nie mogło dojść nawet z powodów formalnych: Bractwo funkcjonowało krótko, a spotkania jego członków nie były regularne. Przez to do wypracowania spójnego stanowiska nie doszło, a opinie poszczególnych osób wyartykułowane w ich zeznaniach podczas śledztwa potwierdzają ich zindywializowane interpretacje wspólnego programu, który zresztą nie został zrealizowany.

Co prawda należy także przyznać rację badaczom nadmieniającym, iż zeznania członków Bractwa wypada traktować z pewnym dystansem, gdyż nie zawsze odzwierciedlają one rzeczywisty stan rzeczy. Jak twierdzi Stefan Kozak, „byłoby grubym nieporozumieniem traktować owe śledcze zeznania, pełne wybiegów, krętactw i uników kijowskich spiskowców wobec ich carskich prześladowców, jako wiarygodne źródło ich przekonań i poglądów. Nie należy przecież zapominać, iż zeznawali pod presją siły, strachu, psychicznego rozstroju i załamania, oraz że musieli się jakoś bronić przed grożącymi im ostrymi sankcjami carskimi"18. Rzeczywiście, zachowane dokumenty ze sprawy śledczej zawierają sporo nieporozumień, nierzadko wynikających z okoliczności przeprowadzenia samego śledztwa, w którym zdecydowanie brakowało dowodów winy cyrylometodyjczyków.

17 Кирило-Мефодї̈вське товариство, упор. І. Глизь та ін. у 3 т., Kijów 1990, t. 3, s. 292-293.

18 S. Kozak, dz. cyt., s. 137. 


\section{Znaczenie Bractwa}

Badacze ukraińscy zwykle podkreślają, że organizacja cyrylometodyjczyków miała ogromne znaczenie w zakresie historiografii narodowej, gdyż okazała się pierwszą, choć nieudaną, próbą zadeklarowania dążeń narodowowyzwoleńczych Ukraińców w XIX wieku ${ }^{19}$. Nie zaprzeczając, warto jednakże dodać, że Bractwo przejawiało szersze ambicje, głosząc i rozstrzygając kwestię ogólnosłowiańską. Postulaty chrześcijańskie, które posłużyły za zalążek programowy, nawiązują do wartości uniwersalnych - dlatego doświadczenie Bractwa zasługuje na przewartościowanie także w kontekście szeroko pojętej współczesności. Rozeznania naukowe na ten temat nie są wystarczające, a postrzeganie Bractwa w kontekście słowiańskim czy europejskim zdarza się nader rzadko.

\section{Kwestia słowiańska}

Mimo że poglądy spiskowców kijowskich nie były spójne we wszystkim i nie do końca zostały sprecyzowane, reprezentują one typowo romantyczne ujęcie narodu i wspólnoty, zawierają też charakterystyczną mityzację narodu i jego roli w dziejach. Sprawa słowiańska była postrzegana przez młodych intelektualistów z całą powagą. W punkcie 1. Głównych zasad Bractwa czytamy: „Przyjmujemy, iż duchowe i polityczne zjednoczenie Słowian jest ich przeznaczeniem, do którego powinni dążyć" ${ }^{20}$. Te zdanie jest pierwsze nie tylko według porządku, jest ono nadrzędne w dokumentach Bractwa i wskazuje na to, że losy narodów słowiańskich były członkom organizacji bardzo bliskie.

Interesy wzajemności słowiańskiej stanowią punkt wyjścia w całym programie ideowym cyrylometodyjczyków. Byt narodu ukraińskiego ciągle wyobrażali sobie w bezpośrednim związku z rozwojem Słowiańszczyzny, co znalazło odzwierciedlenie w dokumentach programowych stowarzyszenia, mianowicie w Statucie Stowiańskiego Bractwa Św. Cyryla i Metodego, Gtównych zasadach Bractwa, Odezwie do braci Ukraińców, Odezwie do braci Wielkorosjan i Polaków. Według tych dokumentów członkowie Bractwa mieli służyć zaakcep-

19 Д. Чижевський, Нарис з історії філософї на Україні, s. 109; Д. Дорошенко, Нарис історї̈ Украӥни, Lwów 1991, s. 508-509; В.П. Шевчук, М.Г. Тараненко, Історія української державності, Kijów 1999, s. 157.

20 Кирило-Мефодї̈вське товариство, t. 3, s. 150. 
towanym przez nich celom poprzez pracę organiczną, głosząc idee wolności, równości i miłosierdzia chrześcijańskiego oraz wychowując młode pokolenie w odpowiednim duchu. Należało też przeciwstawiać się próbom skłócenia narodów słowiańskich czy pogardy jednego narodu wobec innego. Ta pozycja wyraźnie odróżnia intelektualistów ukraińskich od słowianofilów rosyjskich, którzy dominację narodu rosyjskiego w świecie słowiańskim uważali za coś naturalnego i nie podawali w wątpliwość. Natomiast w myśli Kostomarowa i Biłozerskiego (ponieważ to do nich należy autorstwo dokumentów programowych organizacji) równe prawa wszystkich plemion słowiańskich były traktowane jako pretekst wyimaginowanej federacji narodów, która przecież miała być budowana na wzajemnym szacunku i zaufaniu, a także na zbiorowej odpowiedzialności wobec przyszłych pokoleń.

Idea słowiańskiej wzajemności, sformułowana w myśli cyrylometodyjczyków, nawiązuje do szerszego kontekstu ideologii słowiańskiej w XIX wieku. Na jej kształcie odcisnęła piętno koncepcja słowianofilska rozwinięta w dziełach czesko-słowackich budzicieli: Jána Kollára, Václava Hanki, Pavla Šafárika, L'udovíta Štúra (o wpływie tych twórców na upowszechnienie słowianofilstwa pisał w swoich ówczesnych wierszach Taras Szewczenko). Jeszcze bardziej widoczne w dokumentach Bractwa okazały się wpływy polskiej literatury romantycznej. Sama kreacja mesjanizmu w zakresie słowiańskim także zapożyczona została z polskiej myśli politycznej z okresu porozbiorowego. Wypada w związku z tym wspomnieć zwłaszcza słynny traktat Adama Mickiewicza Księgi narodu i pielgrzymstwa polskiego (1832). Mykoła Kostomarow na pewno wzorował się na tym utworze, pisząc program Bractwa ${ }^{21}$. Tak samo jak jego poprzednik, wybitny poeta polski, przedstawiał dzieje Ukrainy jako proces nieustannej walki o swobodę, a narodowe zniewolenie postrzegał jako istną tragedię narodu. Stara Ukraina-Małorosja według Kostomarowa stanowczo broniła swoich praw, przede wszystkim wiary i wolności, dlatego jest w stanie zrozumieć intencje innych narodów, które tak samo doznały krzywdy w swych dziejach. Opinie autora Ksiag rodzaju Narodu Ukraińskiego opierały się na tradycji literatury romantycznej, w której zostało uformowane uję-

21 Traktat Księgi rodzaju Narodu Ukraińskiego (1846) jest utworem anonimowym. Badacze przeważnie wskazują Mykołę Kostomarowa jako jego ewentualnego autora. Zob. Державні, політичні та громадські діячі України, за ред. М. Панова, кн. 1, Kijów 2002, s. 187. 
cie Ukraińców jako narodu dzielnego, kochającego i ceniącego wolność nade wszystko, potrafiącego ją bronić w sytuacji opresyjnej. W taki oto sposób Kozacy-Ukraińcy byli zobrazowani między innymi w polskim pisarstwie romantycznym, zwłaszcza przez przedstawicieli szkoły ukraińskiej22. Podobieństwa i analogie Ksiag Mickiewicza i Ksiag rodzaju Narodu Ukraińskiego przytacza Stefan Kozak, podając dowody wpływu dzieła Mickiewiczowskiego na poglądy Mykoły Kostomarowa ${ }^{23}$.

Widząc w utracie wolności klęskę nowych czasów, autor Ksiag rodzaju Narodu Ukraińskiego wyraża optymizm wobec przyszłości swego narodu i całej Słowiańszczyzny. Jest to postawa nowatorska, gdyż we wczesnym romantyzmie dominowała opinia pesymistyczna, skoncentrowana przede wszystkim na przeszłości narodu, nawołująca do zachowania skarbów kulturalnych. Ta pesymistyczna wizja Ukrainy została zweryfikowana dopiero później, po ukazaniu się drukiem znakomitego Kobziarza Tarasa Szewczenki (1840). To Szewczenko, wywarłszy ogromny wpływ na współczesną mu inteligencję ukraińską, przekonał ją, że warto nie tylko opłakiwać heroiczną przeszłość ziemi rodzimej, ale także zadbać o jej przyszłość24. Program ideowy Bractwa był właściwą odpowiedzią na zmianę romantycznych wyobrażeń o Ukrainie i Ukraińcach. Utrzymuje bowiem, że z biegiem czasu dojdzie do odrodzenia plemion słowiańskich, a ojczyzna powstanie w ich gronie jako wzór cnoty chrześcijańskiej i tradycji wolnościowej. W zakończeniu deklaracji autor oświadcza:

Albowiem głos Ukrainy nie ucichł. I wstanie ona ze swojej mogiły, i odezwie się do wszystkich swoich braci Słowian, i usłyszą jej wołanie, i wstanie Słowiańszczyzna

22 M. Janion, Kozacy i Górale, [w:] Z dziejów stosunków literackich polsko-ukraińskich. Praca zbiorowa, red. S. Kozak, M. Jakóbiec, Wrocław 1974, s. 139; A. Witkowska, „Dziko - pięknie groźnie”, czyli Ukraina romantyków, [w:] Szkoła ukraińska w romantyzmie polskim. Szkice polskoukraińskie, red. S. Makowski, U. Makowska i M. Nesteruk, Warszawa 2012, s. 24-25.

23 S. Kozak, Polacy i Ukraińcy. W kręgu myśli i kultury pogranicza. Epoka romantyzmu, Warszawa 2005, s. 157-184.

24 Jak pisze George Grabowicz, Taras Szewczenko ujrzał w swej poezji nie tylko koniec (upadek) Ukrainy, lecz również jej początek. Co więcej, sam jawił się jako prorok odrodzenia swego narodu. Zob. Г. Грабович, Грані мітичного: образ Украйни в польському й украйнському романтизмі, [w:] tegoż, До історії української літератури. Дослідження, есеї, полеміка, Kijów 2003, s. 167-168. 
i wówczas nie będzie już ani cara, ani carewicza, ani barona, ani pana, ani bojarzyna, ani poddanego, ani chłopa pańszczyźnianego - ani w Rosji, ani w Polsce, ani w Ukrainie, ani u Czechów, ani u Chorwatów, ani u Serbów, ani u Bułgarów.

I Ukraina stanie się niepodległą Rzeczpospolitą w federacji słowiańskiej. Wtedy wszystkie narody, pokazując na mapie to miejsce, gdzie narysowana jest Ukraina, powiedzą: Kamień, który odrzucili budujący, stał się głowicą węgła25.

Rozwiązanie przez administrację carską Bractwa Słowiańskiego w roku 1847 położyło kres tej oryginalnej wersji słowianofilstwa. A szkoda, bo w dokumentach programowych stowarzyszenia (w małym zaś stopniu również w konkretnych działaniach, gdyż organizacja dopiero stawała na nogi) zadeklarowano rozważania najbardziej trudnych kwestii ruchu słowiańskiego na tamtym etapie, mianowicie tezę o protektoracie władców rosyjskich bądź o pogardliwym traktowaniu ludów zniewolonych przez władzę imperialną, o zasadach równouprawnienia narodów słowiańskich, o układzie federacyjnym i jego pryncypiach (niektórzy badacze twierdzą, że chodziło tu raczej o konfederację) $)^{26}$.

Nie patrząc na to, że Bractwo św. Cyryla i Metodego nie zdążyło zrealizować poważnych inicjatyw, jego nagłe zamknięcie przez władze carskiej Rosji wywołało pewien rezonans w prasie europejskiej. O rozwiązaniu stowarzyszenia i areszcie jego uczestników pisały gazety paryskie „Jornal des debat” i „Democratic pasifiqe”. Zareagowała na areszt członków Bractwa także prasa wiedeńska ${ }^{27}$, co było niesłychanie ważnym sygnałem dla działaczy z terenów Słowiańszczyzny Zachodniej i Południowej. W Galicji zdarzenie to było bacznie obserwowane przez środowiska rusińskie i polskie. W gazecie „Dnewnyk Ruśkyj” został zamieszczony wiersz polskiego poety Jabłońskiego pt. Męczennikom wolności z roku 1847. W redakcyjnym artykule Słowo o Rusi i jej stanowisku politycznym mieścił się apel o solidarność z aresztowanymi intelektualistami kijowskimi, którzy reprezentowali przecież ,głos narodu walczącego w pętach despotii, wołanie męczenników sprawy ludowej Szewczenki, Ko-

25 Tłumaczenie polskie podaję według K. Wóycickiego: https://kazwoy.wordpress. com/ksiega-rodzaju-narodu-ukrainskiego-prawo-boze-tlumaczenie-robocze/.

26 Кирило-Мефодіївське товариство, t. 3, s. 170.

27 Tamże, s. 10. 
stomarowa, Kulisza i innych"28. Tego typu fakty świadczą o tym, że zamknięcie Bractwa oraz represje wobec jego członków były odebrane w ówczesnym świecie jako przejaw przemocy i nadużycia ze strony władz carskiej Rosji, które w ten sposób wykazały swoje intencje despotyczne.

Ukraińska wizja Słowiańszczyzny, realizowana w postaci kijowskiego Bractwa św. Cyryla i Metodego, była ruchem typowo romantycznym, wynikającym z europejskiej tradycji libertańskiej i kontynuującym sprawę aktywistów słowiańskich w pierwszej połowie XIX wieku. Oczywiście, miała ona cechy projektu utopijnego, przedstawiała idylliczne rozwiązanie problemu politycznego. Cyrylometodyjczycy zmierzali do przywrócenia praw narodowych wszystkim Słowianom, a przy tym uzasadniali swój projekt przez oparcie na wartościach chrześcijańskich. To z kolei sprawiło, że ta podziemna organizacja nie ograniczała się do efektu lokalnej, reprezentującej konkretny region i jego mieszkańców, lecz głosiła przekaz uniwersalny, skierowany do całej ludzkości. „Uniwersalne wartości chrześcijańskie legły u podstaw programowych założeń Bractwa Cyrylo-Metodyjskiego, zdecydowały o wysokich ideałach etycznych jego członków"29, przyznaje W. Mokry. Mimo to, ostra reakcja władz ówczesnego Imperium Rosyjskiego pokazała, że nawet lojalna i postępowa działalność w duchu solidarności słowiańskiej jest postrzegana z podejrzliwością i nieufnością. Dlatego dobre pomysły spiskowców kijowskich nie mogły być realizowane, a prześladowanie członków Bractwa na długo zahamowało rozwój słowianofilstwa na Ukrainie, a także skierowało ów ruch w inną stronę, nadając mu kształt monarchiczny w całej Rosji.

29 W. Mokry, dz. cyt., s. 167. 


\section{Bibliografia}

Bojko M., Kyryło-Mefodijiwśke towarystwo: fiłosofśki ta kulturołohiczni ideji nacionalnoji samoswidomosti ta derżawotworennia, Dniprodzerżynśk 2006.

Bracka M., Idee kijowskiego Bractwa Cyryla i Metodego (1846-1847) w świetle krytyki postkolonialnej, „Bibliotekarz Podlaski” 2015, nr 30, s. 43-55.

Czyżewśkyj D., Poriwnialna istorija słowjanśkych literatur, per. z nim., Kijów 2005.

Czyżewśkyj D., Narys z istoriji fiłosofiji na Ukrajini, New York 1991.

Derżawni, polityczni ta hromadśki dijaczi Ukrajiny, za red. M. Panowa, kn.1, Kijów 2002.

Doroszenko D., Narys istoriji Ukrajiny, Lwów 1991.

Heorhyewa T., Sławianskata ydeja w Rusyja. 30-te-50-te hodyny na XIX wek, Sofyja 2009.

Hrabowycz H., Hrani mitycznoho: obraz Ukrajiny w polśkomu j ukrajinśkomu romantyzmi, [w:] tegoż, Do istoriji ukrajinśkoji literatury. Doslidżennia, eseji, połemika, Kijów 2003, s. 157-179.

Janion M., Kozacy i Górale, [w:] Z dziejów stosunków literackich polsko-ukraińskich. Praca zbiorowa, red. S. Kozak, M. Jakóbiec, Wrocław 1974, s. 135-170.

Kozaczok Ja., Horłenko O., Zabuttiu ne pidlahaje. Mykoła Kostomarow i KyryłoMefodijiwśke towarystwo, Kyjiw 2007.

Kozak S., Polacy i Ukraińcy. W kręgu myśli i kultury pogranicza. Epoka romantyzmu, Warszawa 2005.

Kozak S., Ukraińscy spiskowcy i mesjaniści. Bractwo Cyryla i Metodego, Warszawa 1990.

Księga rodzaju narodu ukraińskiego (Prawo Boże) (tłum. robocze K. Wóycicki), https://kazwoy.wordpress.com/ksiega-rodzaju-narodu-ukrainskiego-prawo-bozetlumaczenie-robocze/

Kyryło-Mefodijiwśke towarystwo, upor. I. Hłyź ta in.: u 3 t., Kijów 1990, t. 3.

Miller A., Imperija Romanowych i nacionalizm. Esse po metodołogii istoriczeskogo issłedowanija, Moskwa 2008, s. 34-35.

Mokry W., Literatura i myśl filozoficzno-religijna ukraińskiego romantyzmu, Kraków 1990.

Sobol W., Ukrajinśke baroko. Teksty i konteksty, Warszawa 2015.

Szewczuk W. P., Taranenko M. H., Istorija ukrajinśkoji derżawnosti, Kijów 1999.

Wisbert R., Historia i edukacja w koncepcjach Johanna Gottfrieda Herdera, [w:] Ro- 
zum i świat. Herder i filozofia XVIII, XIX i XX wieku, red. M. Heinz, M. Potępa i Z. Zwoliński, Warszawa 2004.

Witkowska A., "Dziko - pięknie - groźnie”, czyli Ukraina romantyków, [w:] Szkoła ukraińska w romantyzmie polskim. Szkice polsko-ukraińskie, red. S. Makowski, U. Makowska i M. Nesteruk, Warszawa 2012.

Wozniak M., Kyryło-Mefodijiwśke Bratstwo, Lwiw 1921.

Zajonczkowskyj P., Kyryllo-Mefodyewskoe obszczestwo. 1845-1847, Moskwa 1959.

Zorin A., Kormia dwugławogo orła... Literatura i gosudarstwennaja ideołogija w Rossii w posledniej treti XVIII - perwoj trety XIX wieka, Moskwa 2004. 